\title{
Alleviation of Drought Stress in Vicia faba by Seed Priming with Ascorbic Acid or Extracts of Garlic and Carrot
}

\author{
Wedad A. Kasim", Afaf A. Nessem and Azza Gaber \\ Botany Department, Faculty of Science, Tanta University, Tanta, Egypt.
}

\begin{abstract}
$\mathbf{T}$ HIS STUDY was carried out to assess the harmful effects of drought stress on Vicia faba L. (cv. Giza 716) and to evaluate the role of priming of the seeds in the extract of carrot root, garlic cloves or in ascorbic acid in the alleviation of these harmful effects. Fourteen days old Vicia faba seedlings grown from primed seeds were subjected to water withholding for 14 days (D1) or 22 days (D2), then left to grow till 40 days. The results revealed that the two levels of drought stress significantly decreased shoot height, fresh and dry masses and water content of root and shoot, as well as leaf area, but they increased root length of 40-days-old plants. Photosynthetic pigments ( $\mathrm{chl}$ a and $\mathrm{chl}$ b), chlo a/chl b ratio, photosynthetic activity, sucrose and starch content were also decreased under the effect of both periods of drought stresses. On the other hand, carotenoid contents, the activities of catalase and peroxidase, ascorbic acid, malondialdehyde (MDA), glucose and total soluble protein contents were increased in leaves. Priming of Vicia faba seeds with the extracts of carrot root (Daucus carota L.), garlic cloves (Allium sativum L.) or with ascorbic acid mitigated all of the recorded harmful effects of drought stress, while they decreased carotenoids, activities of catalase and peroxidase, ascorbic acid, MDA, glucose and total soluble protein contents.
\end{abstract}

Keywards: Antioxidant, Ascorbic acid, Carrot extract, Drought, Garlic extract, Osmolyte, Vicia faba.

\section{Introduction}

Faba bean (Vicia faba L.) is an important crop due to its high protein content (about $30 \%$ ) and its significant value in improving the fertility of soil by fixing nitrogen in symbiosis which makes them excellent colonizers of low-N environments (Abdelmula et al., 2012 and Khazaei, 2014).

Drought stress is the most important environmental factor which introduces morphological, physiological, biochemical and molecular changes in plants (Siddiqui et al., 2015 and Abid et al., 2016). A common adverse effect of water stress on crop plants is the reduction in fresh and dry biomasses as recorded in chickpea (Samarah, 2005), common bean (Abass \& Mohamed, 2011) and Soybean (Mohamed \& Akladious, 2014). Drought, as an abiotic stress, inhibits the process of photosynthesis in most plants by altering the ultrastructure of the organelles (Kasim et al., 2014 and Mahmoud, 2014) and the concentration of various pigments and metabolites including enzymes involved in this process as well as stomatal regulation (Ashraf \& Harris, 2013). Under abiotic stress conditions, such as severe drought, cellular homeostasis is disrupted and leads to the production of relatively high levels of ROS such as $\mathrm{H}_{2} \mathrm{O}_{2}, \mathrm{O}_{2}^{-}$, singlet $\mathrm{O}_{2}{ }^{1}$ and $\mathrm{OH}^{-}$radicals, through enhanced leakage of electrons to molecular oxygen causing oxidative damage to the photosynthetic apparatus and damage of vital cellular macromolecules (Kusvuran, 2012).

The adverse effects of different abiotic stresses can be mitigated by application of natural plant extracts as carrot root (Abbas \& Akladious, 2013), or garlic cloves (Mohamed \& Akladious, 2014), or by chemical materials as ascorbic acid (Abdul Qados, 2014). Carrot (Daucus carota L.) is the most important root vegetable plant belonging

"Corresponding author e-mail: wedkasim@yahoo.com 
to Apiaceae (Umbellefereae). It has been used as amendments in plant growth due to the presence of a number of plant growth-stimulating compounds because its extract is known to have a high content of vitamin A (as $\beta$-carotene), protein, carbohydrates, fat and vitamin, bio-regulators as B1, B2, B6, C, D and E which are antioxidants that reduce free radicals and cell damage (Baranska et al., 2005). Garlic (Allium sativum L.) is a bulb producing crop in the family Alliaceae, has a very strong pungent odour and it is known to contain an essential oil rich in sulphur-containing compounds such as aliin, allicin, ajoene, allylpropyl, diallyl, trisulfide, sallylcysteine, vinyldithiines, sallylmercaptocystein, and others (Mohamed \& Akladious, 2014). According to these authors, garlic cloves contain $0.1-0.36 \%$ of a volatile oil which is responsible for most of its pharmacological properties.

Hasanuzzaman et al. (2013) and Ahmed et al. (2014) maintained that ascorbic acid is one of the strongest non-enzymatic antioxidants in plant tissue which is synthesized in the cytosol of higher plants primarily from conversion of d-glucose to ascorbic acid. It prevents or decreases the oxidative damage and reduces $\mathrm{H}_{2} \mathrm{O}_{2}$ to water by acting as an ascorbate peroxidase substrate in ascorbate peroxidase reaction in the chloroplast stroma under drought stress (Athar et al., 2008; El-Beltagi \& Mohamed, 2013 and Yu et al.,2014).

The aim of the present study was to assess the effect of two levels of drought stress on the growth and some physiological processes inVicia faba plants and to evaluate the role of seed priming naturally with carrot root or garlic cloves extract or with a chemical material such as ascorbic acid in the alleviation of these harmful effects.

\section{Material and Methods}

\section{Plant materials}

Seeds of Vicia faba (cv. Giza 716) were supplied by the Agricultural Research Center, Giza, Egypt, and selected for apparent uniformity of size and shape. Fresh plants of carrot roots and garlic cloves were obtained from the local market.

\section{Preparation of the extracts}

Carrot root extract (Cr) was prepared according to Sofowora (1982) with some modifications; an amount of $200 \mathrm{~g}$ of the washed fresh carrot roots were sliced into tiny pieces and blended in an electric blender with $640 \mathrm{ml}$ of tap water. These were filtered through filter paper (Whatman No.1) and the filtrate was increased to one liter with tap water and this concentration was considered as $100 \%$ carrot extract. Garlic extract (G) was prepared according to Hanafy et al. (2012) with some modifications: about $250 \mathrm{~g}$ of the newly produced garlic cloves were put in 250 $\mathrm{ml}$ water, frozen for one day and then left to thaw. Freezing and thawing were repeated three times. They were blended, filtered through filter paper (Whatman No.1) and the filtrate was increased to one liter with water and this concentration was considered as $100 \%$ garlic extract. Ascorbic acid solution was prepared with a concentration of 0.5 $\mathrm{mM}$.

\section{Analysis of garlic and carrot extracts}

Phytohormones (GA, IAA and ABA), and two cytokinins (kinetin and benzyl adenine) were determined in the carrot root and garlic gloves extracts according to Shindy \& Smith (1975). The mixed acid-digestion method was used for element measurement in carrot root and garlic gloves tissues according to Allen et al. (1974) and determination of $\mathrm{P}, \mathrm{Ca}, \mathrm{Mg}, \mathrm{Fe}, \mathrm{Mn}, \mathrm{Zn}, \mathrm{Cu}$ and Se were carried out in the two extracts using Inductively Coupled Plasma (ICP) Spectrometry (Ultima 2 JY Plasma) according to the procedure of the "Environmental Protection Agency" EPA (1991). The procedure described by A.O.A.C. (1990) were used in the determination of $\mathrm{S}, \mathrm{N}_{2}$ (by the Kjeldahl method), and $\mathrm{Na}$ and $\mathrm{K}$ ions (by the Flame Photometer). Carotenoids in carrot were determined according to Metzner et al. (1965). In both carrot root and garlic gloves extract, ascorbic acid (As) was estimated according to Oser (1979) and total soluble carbohydrates were estimated according to Dubois et al. (1956).

\section{Cultivation and drought stress treatment}

Four groups of Vicia faba seeds were primed by soaking for $10 \mathrm{~h}$ either in tap water (as control), $100 \%$ garlic extract, $100 \%$ carrot extract or $0.5 \mathrm{mM}$ ascorbic acid. Thereafter, 10 soaked seeds of each group were sown in plastic pots $(25 \mathrm{~cm}$ diameter and $20 \mathrm{~cm}$ depth), where each pot contained $5 \mathrm{~kg}$ clay-sandy soil $(2: 1 \mathrm{w} / \mathrm{w})$. The seeds were irrigated with tap water once daily for three days, then irrigated with $60 \%$ of field capacity twice weekly and left to grow for 14 days under natural environmental conditions $\left(16 / 8 \mathrm{~h}\right.$ day/night at $25^{\circ} \mathrm{C} / 15^{\circ} \mathrm{C} \pm 2 \mathrm{day} /$ night and relative humidity of $65 \%$ ), then subjected to 
water with holding for 0.0 days (control); 14 days (D1), or 22 days (D2) then re-irrigated with water twice weekly till the end of experiment (40 days).

\section{Growth criteria and physiological analyses}

Growth criteria (root length, shoot height, fresh and dry masses and water content of root and shoot, as well as leaf area) were determined for the 40-days-old Vicia faba plants. Photosynthetic pigments (Chl. a, Chl. b and carotenoids) were determined according to Metzner et al. (1965) and photosynthetic activity was measured in the leaves with OS-30 p chlorophyll fluorometer (Hudson, NH03051, USA). The activities of Catalase [EC1.11.1.6] and peroxidase [EC1.11.1.7] were assayed according to Kato \& Shimizu (1987). The non-enzymatic antioxidant, ascorbic acid (As) was estimated according to Oser (1979). MDA concentration was estimated by the method of Heath \& Packer (1968). Carbohydrates were estimated quantitatively using Nelson's method (1944) as modified by Naguib (1963). The total soluble protein content was determined as described by Bradford (1976).

\section{Statistical analysis}

All data were statistically analyzed using one way Analysis of Variance (ANOVA) by COSTAT statistical program to determine the degree of significance for the obtained variations.

\section{$\underline{\text { Results }}$}

The results in Fig. 1 indicate that both levels of drought stress caused highly significant decrease in shoot height and leaf area; where the percentages of decrease with D1 were $16.8 \%$ and $23.7 \%$, respectively; while with D2 they were $45.5 \%$ and $37.2 \%$, respectively relative to the control. On the other hand, D1 and D2 caused highly significant increase in root length; where the percentages of increase were $27.7 \%$ and $46.3 \%$, respectively compared with the control. On priming of Vicia faba seeds by presoaking in G, Cr or As, shoot height and leaf area were increased compared with the corresponding counterparts under drought stress. Moreover, priming not only alleviated the harmful effects of drought, but also resulted in a remarkable increase in root length relative to the drought stressed plants.

Data in Fig. 2 indicate that both levels of drought stress resulted in significant decreases in fresh mass of root and shoot; where the percentages of decrease with D1 were $41.1 \%$ and $24 \%$, respectively while with D2 they were $60 \%$ and $53.6 \%$, respectively relative to the control. Similarly, D1 and D2 resulted in highly significant decreases in dry mass of root and shoot; where the percentages of decrease with D1 were $32.1 \%$ and $20.4 \%$, respectively while with D2 they were $50 \%$ and $46.7 \%$, respectively compared with the control. Moreover, the two drought stress levels decreased water content of root and shoot with percentages of $14.5 \%$ and $4.9 \%$, respectively with D1 and 22.1 $\%$ and $14.2 \%$, respectively with D2 relative to the control. Priming of Vicia faba seeds with G, Cr or As could alleviate the harmful effects of drought stress, where fresh and dry masses and water content of root and shoot were increased compared with the corresponding stressed counterparts under D1 or D2.

The results in Fig. 3 show that both levels of drought stress, D1 and D2, caused highly significant reduction in Chl. a, Chl. b and a/b ratio; where the percentages of decrease with D1 were $24.1 \%, 10.7$ $\%$ and $15.1 \%$, respectively while with D2 they were $28.6 \%, 14.5 \%$ and $16.8 \%$, respectively compared with the control. Similarly, D1 and D2 resulted in a significant decrease in photosynthetic activity with the percentages of $7.9 \%$ and $13.9 \%$, respectively relative to the control. On the other hand, both D1 and D2 resulted in highly significant increase in carotenoids; where the percentages of increase were $22.3 \%$ and $32.6 \%$, respectively compared with the control. The combined treatments of priming of Vicia faba seeds with G, $\mathrm{Cr}$ or As and drought stress indicated significant amelioration of the harmful effects of drought stress, where Chl. a, Chl. $\mathrm{b}, \mathrm{a} / \mathrm{b}$ ratio and photosynthetic activity were increased compared with the drought stressed samples. Moreover, this priming resulted in a remarkable reduction in carotenoids relative to the drought stress samples (Fig. 3).

The results in Fig. 4 reveal that both drought stresses, D1 and D2, resulted in a significant increase in the activities of peroxidase and catalase; where the percentages of increase were $777 \%$ and $93.3 \%$ with D1 and $358 \%$ and $500 \%$ with D2, respectively relative to the control. However, seed priming with $\mathrm{G}, \mathrm{Cr}$ or As, could alleviate the harmful effects of drought stress, where great reductions in peroxidase and catalase activities were determined compared with the corresponding samples under either D1 or D2 but the values remained higher than those in the control. 

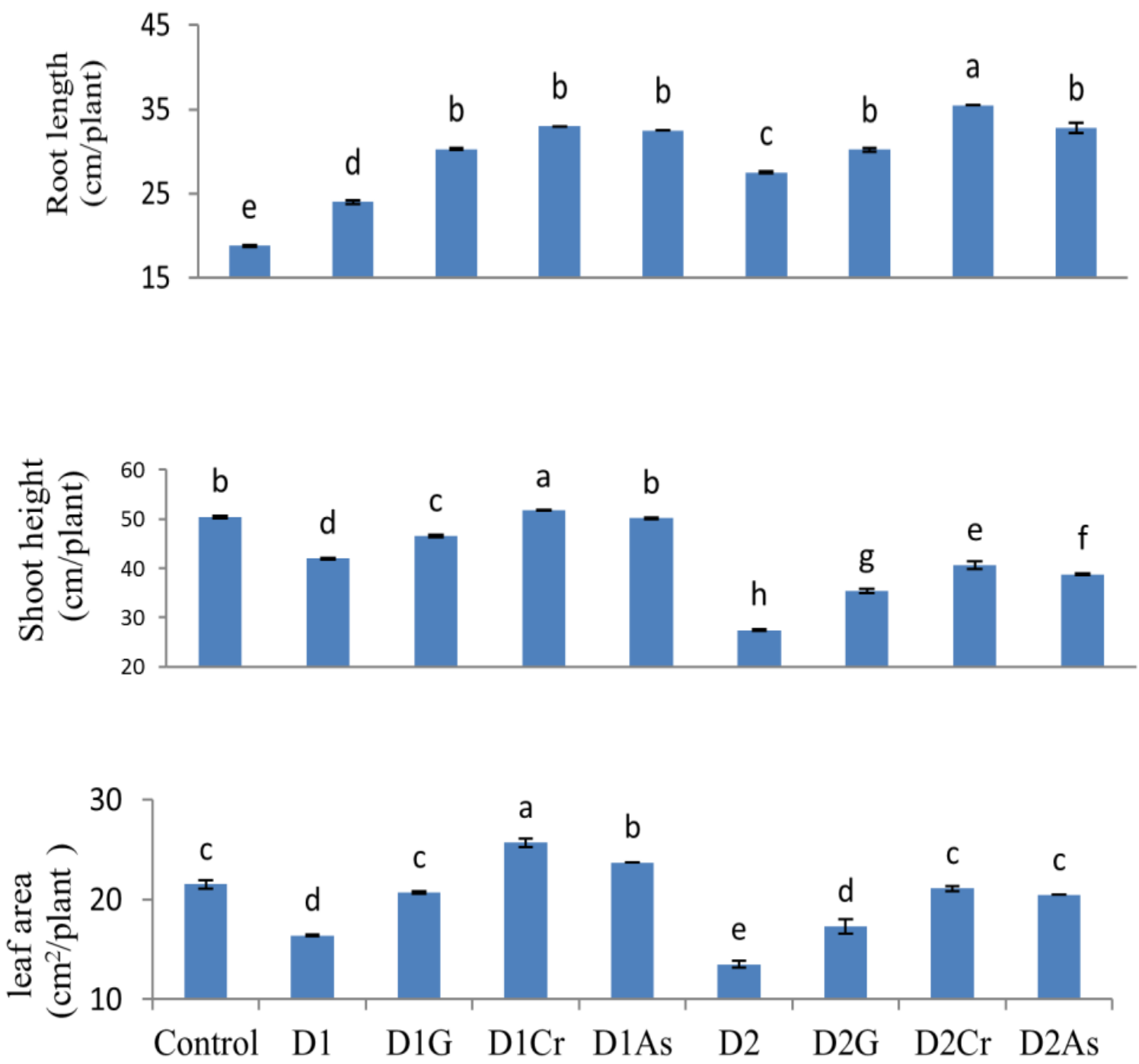

Fig.1. Effect of drought stress on root length, shoot height and leaf area of 40-days-old Vicia faba plants after presoaking the seeds for $10 \mathrm{~h}$. in either of $100 \%$ garlic (G), $100 \%$ carrot $(\mathrm{Cr})$ extracts or $0.5 \mathrm{mM}$ ascorbic acid (As). D1 and D2= water withholding for 14 and 22 days, respectively. Bars indicate standard errors between three replicates. Treatments labeled with identical letters are not significant at $\mathbf{p} \leq \mathbf{0 . 0 1}$.

One way ANOVA analysis $(\mathrm{P} \leq 0.01)(* * *$ highly significant $)$

$\begin{array}{cccc}\text { Parameter } & \text { LSD } & \text { F } & \text { Significance } \\ \text { Root length } & 2.23 & 90.7 & * * * \\ \text { Shoot height } & 0.84 & 1474.5 & * * * \\ \text { Leaf area } & 1.12 & 185 & * * *\end{array}$



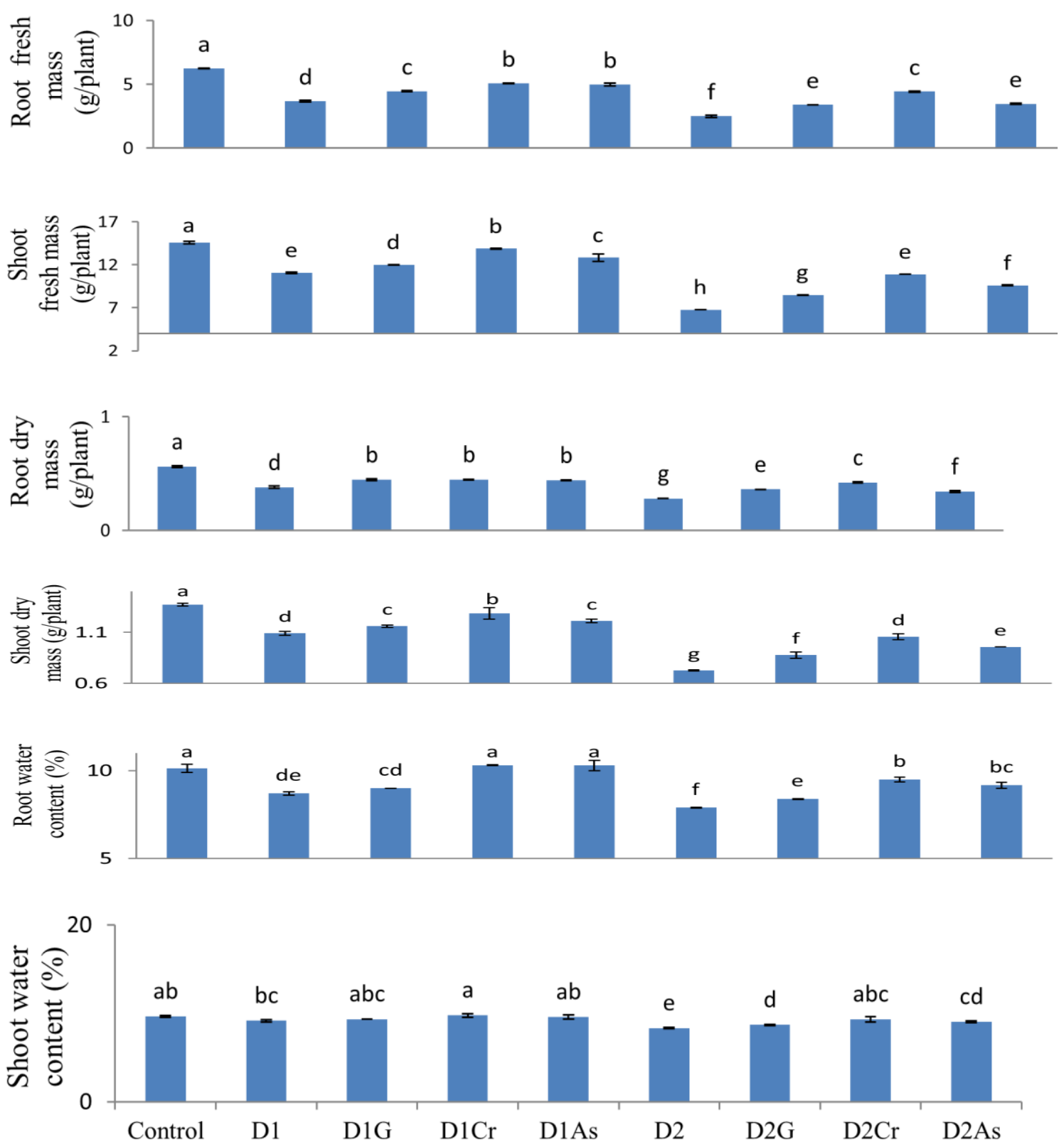

Fig.2. Effect of drought stress on fresh and dry masses and water content of root and shoot of 40-days-old Vicia faba plants after presoaking the seeds for $10 \mathrm{~h}$. in either of $100 \%$ garlic (G), $100 \%$ carrot (Cr) extracts or $0.5 \mathrm{mM}$ ascorbic acid (As). D1 and D2= water withholding for 14 and 22 days, respectively. Bars indicate standard errors between three replicates. Treatments labeled with identical letters are not significant at $p$ $\leq \mathbf{0 . 0 1}$.

\begin{tabular}{|c|c|c|c|c|}
\hline \multicolumn{5}{|c|}{ One way ANOVA analysis $(\mathrm{P} \leq 0.01)(* * *$ highly significant $)$} \\
\hline Parameter & & LSD & $\mathrm{F}$ & Significance \\
\hline \multirow[t]{2}{*}{ Fresh mass } & Root & 0.154 & 876.8 & $* * *$ \\
\hline & Shoot & 0.358 & 833.5 & $* * *$ \\
\hline \multirow[t]{3}{*}{ Dry mass } & Root & 0.015 & 444.6 & $* * *$ \\
\hline & Shoot & 0.061 & 188.3 & $* * *$ \\
\hline & Root & 0.35 & 102.2 & $* * *$ \\
\hline Water content & Shoot & 0.38 & 25.5 & $* * *$ \\
\hline
\end{tabular}



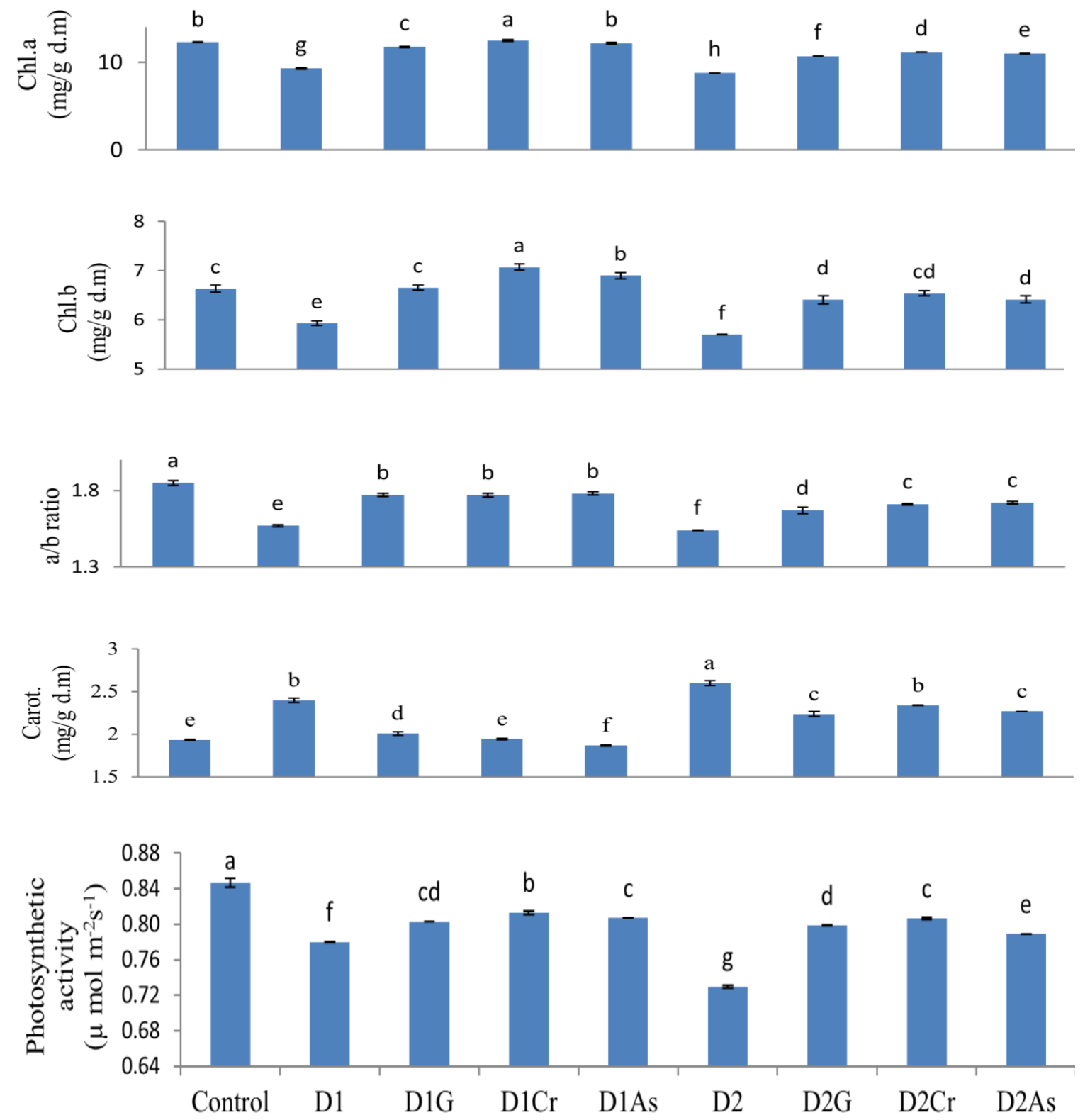

Fig.3. Effect of drought stress on chlorophyll a (Chl. a) and chlorophyll b (Chl.b), chlorophyll (a/b) ratio, carotenoids (Carot.) and photosynthetic activity (fv/fm ratio) of 40-days-old Vicia faba plants after presoaking the seeds for $10 \mathrm{~h}$ in either of $100 \%$ garlic (G), $100 \%$ carrot (Cr) extracts or $0.5 \mathrm{mM}$ ascorbic acid (As). D1 and D2 = water withholding for 14 and 22 days, respectively. Bars indicate standard errors between three replicates. Treatments labeled with identical letters are not significant at $\mathbf{p} \leq \mathbf{0 . 0 1}$.

One way ANOVA analysis $(\mathrm{P} \leq 0.01)(* * *$ highly significant $)$

$\begin{array}{lccc}\text { Parameter } & \text { LSD } & \text { F } & \text { Significance } \\ \text { Chl.a } & 0.125 & 1855 & * * * \\ \text { Chl.b } & 0.144 & 151.3 & * * * \\ \text { Carot. } & 0.042 & 523.7 & * * * \\ \text { a/b } & 0.027 & 231.9 & * * * \\ \text { Photosynthetic activity } & 0.005 & 781.9 & * * *\end{array}$



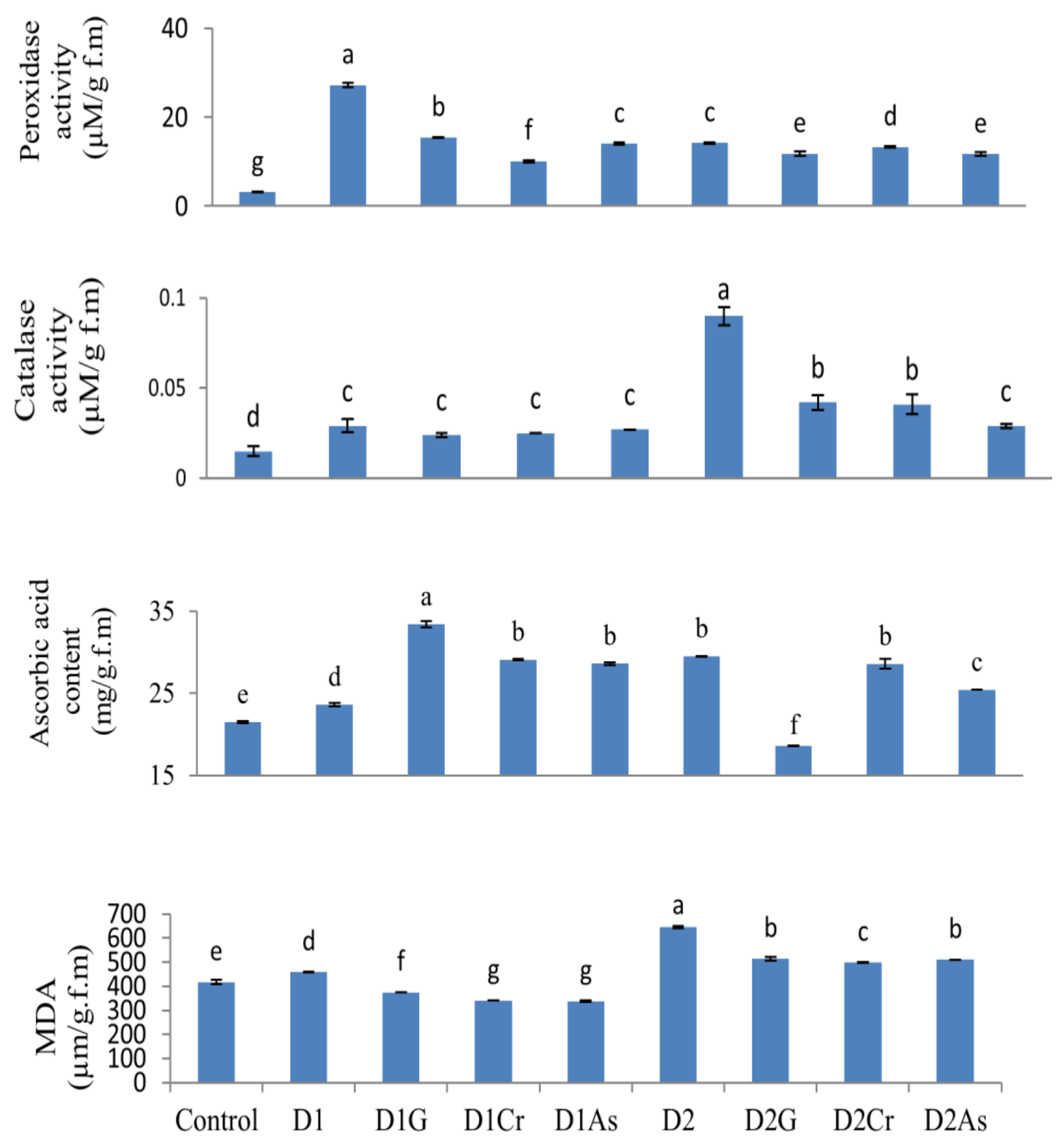

Fig. 4. Effect of drought stress on peroxidase and catalase activities, ascorbic acid and malondialdehyde (MDA) contents of 40-days-old Vicia faba plants after presoaking the seeds for $10 \mathrm{~h}$. in either $100 \%$ garlic (G), $100 \%$ carrot (Cr) extracts or $0.5 \mathrm{mM}$ ascorbic acid (As). D1 and D2= water withholding for 14 and 22 days, respectively. Bars indicate standard errors between three replicates. Treatments labeled with identical letters are not significant at $\mathbf{p} \leq \mathbf{0 . 0 1}$.

One way ANOVA analysis $(\mathrm{P} \leq 0.01)(* * *$ highly significant $)$

$\begin{array}{lccc}\text { Parameter } & \text { LSD } & \text { F } & \text { Significance } \\ \text { Peroxidase } & 0.68 & 1419 & * * * \\ \text { Catalase } & 0.008 & 138.9 & * * * \\ \text { Ascorbic acid content } & 0.753 & 619.0 & * * * \\ \text { MDA } & 9.0 & 2043.0 & * * *\end{array}$


Figure 4 reveal that both levels of drought stress (D1 and D2) resulted in an increase in the ascorbic acid content of Vicia faba; where the percentage of increase was $9.8 \%$ with D1 and was $37.2 \%$ with D2 relative to the control. Priming of Vicia faba seeds by presoaking in $\mathrm{G}$, $\mathrm{Cr}$ or As resulted in an increase in ascorbic acid content relative to the D1-stressed samples; while in case of $\mathrm{D} 2$, all priming resulted in the reduction of ascorbic acid content compared with the D2stressed plants.

As shown in Fig. 4, both D1 and D2 resulted in a significant increase in MDA content; where the percentages of increase were $9.8 \%$ and $54.8 \%$, respectively relative to the control. However, priming of Vicia faba seeds with $\mathrm{G}, \mathrm{Cr}$ or As decreased MDA content in both D1 and D2 stressed plants compared with their corresponding stressed samples.

Results in Fig. 5 show that both drought stress levels caused highly significant increase in glucose and total soluble proteins, where the percentages of increase were $90.4 \%$ and $141 \%$ with D1 and $145.5 \%$ and $124 \%$ with D2, respectively relative to the control. On the other hand, D1 and D2 caused highly significant reduction in sucrose and starch; where the percentages of decrease were $34.8 \%$ and $22.1 \%$ with D1, respectively; and with D2 they were $59.4 \%$ and $58.2 \%$, respectively relative to the control. Presoaking of Vicia faba seeds in $\mathrm{G}, \mathrm{Cr}$ or As, could alleviate the inhibitory effects of drought stress, where it resulted in a remarkable reduction of glucose. However, total soluble protein was also decreased by priming compared with the corresponding samples under drought stress D1 and the values were higher than those of the control; while in case of D2, it was increased compared with the corresponding samples under D2. Similarly, sucrose and starch were increased in the primes-stressed plants compared with the drought stressed ones.

As shown in Table 1, both garlic cloves and carrot root contain elementsas $\mathrm{P}$ and $\mathrm{Na}$, micronutrients as $\mathrm{Fe}, \mathrm{Mn}, \mathrm{Zn}$ and $\mathrm{Cu}$, macronutrients as $\mathrm{S}, \mathrm{Ca}, \mathrm{K}, \mathrm{Mg}$ and $\mathrm{N}_{2}$, and they also contain carbohydrates and ascorbic acid (vitamin $\mathrm{C}$ ). In both garlic and carrot, the highest concentration was recorded for $\mathrm{K}$, while the lowest was found for $\mathrm{Se}$ in garlic and for $\mathrm{S}$ in carrot. Furthermore, Se was present in garlic and absent in carrot, while $\beta$ carotene (the precursor of vitamin A) was detected in carrot but not in garlic. Table 1 also revealed that the extracts of garlic and carrot contain acidic phytohormones as GA, IAA and ABA and cytokinins as kinetin and benzyl adenine; where the highest concentration was found for GA but the lowest was for benzyl adenine, in both extracts.

TABLE 1. Mineral analysis, carbohydrate content, ascorbic acid content and phytohormone analysis of extracts of garlic cloves and carrot roots. $\mathrm{P}=$ phosphorus, $\mathrm{Na}=$ sodium, $\mathrm{Se}=$ selenium, $\mathrm{Fe}=$ iron, $\mathrm{Mn}$ = manganese, $\mathrm{Zn}=$ zinc, $\mathbf{C u}=$ copper, $\mathrm{S}=$ sulfur, $\mathbf{C a}=$ calcium, $\mathrm{K}=$ potassium, Mg=magnesium, $\quad \mathbf{N}_{2}=$ nitrogen, $\quad \mathbf{G A}=$ gibberellic acid, IAA=Indole acetic acid, ABA=abscisic acid.

\begin{tabular}{|c|c|c|}
\hline \multirow{2}{*}{ Elements } & Garlic extract & $\begin{array}{l}\text { Carrot } \\
\text { extract }\end{array}$ \\
\hline & (mg/g d.m) & (mg/g d.m) \\
\hline $\mathrm{P}$ & 4.61 & 1.3452 \\
\hline $\mathrm{Na}$ & 5.04 & 1.2052 \\
\hline $\mathrm{Se}$ & $1.08(\mu \mathrm{g} / \mathrm{g}$ d.m $)$ & 0.00 \\
\hline $\mathrm{Fe}$ & 0.0304 & 0.052 \\
\hline $\mathrm{Mn}$ & 0.6044 & 0.372 \\
\hline $\mathrm{Zn}$ & 0.3360 & 0.195 \\
\hline $\mathrm{Cu}$ & 0.0395 & 0.073 \\
\hline S & 0.015 & 0.025 \\
\hline $\mathrm{Ca}$ & 2.146 & 0.635 \\
\hline K & 6.040 & 5.832 \\
\hline $\mathrm{Mg}$ & 0.802 & 0.735 \\
\hline $\mathrm{N}_{2}$ & 0.440 & 0.090 \\
\hline Carbohydrates & 573 & 241.5 \\
\hline Ascorbic acid & $\begin{array}{c}1.54 \\
(\mathrm{mg} / \mathrm{g} \text { f.m) }\end{array}$ & $\begin{array}{c}1.51 \\
(\mathrm{mg} / \mathrm{g} \text { f.m) }\end{array}$ \\
\hline Carotenoids & 0.0 & $\begin{array}{c}0.025 \\
\text { (mg/g f.m) }\end{array}$ \\
\hline Hormones & $(\mu \mathrm{g} / 100 \mathrm{ml})$ & $(\mu \mathrm{g} / 100 \mathrm{ml})$ \\
\hline GA & 374 & 976.0 \\
\hline IAA & 20 & 23.0 \\
\hline ABA & 45 & 15.0 \\
\hline Kinetin & 23.12 & 67.1 \\
\hline Benzyl Adenine & 4.18 & 14.6 \\
\hline
\end{tabular}



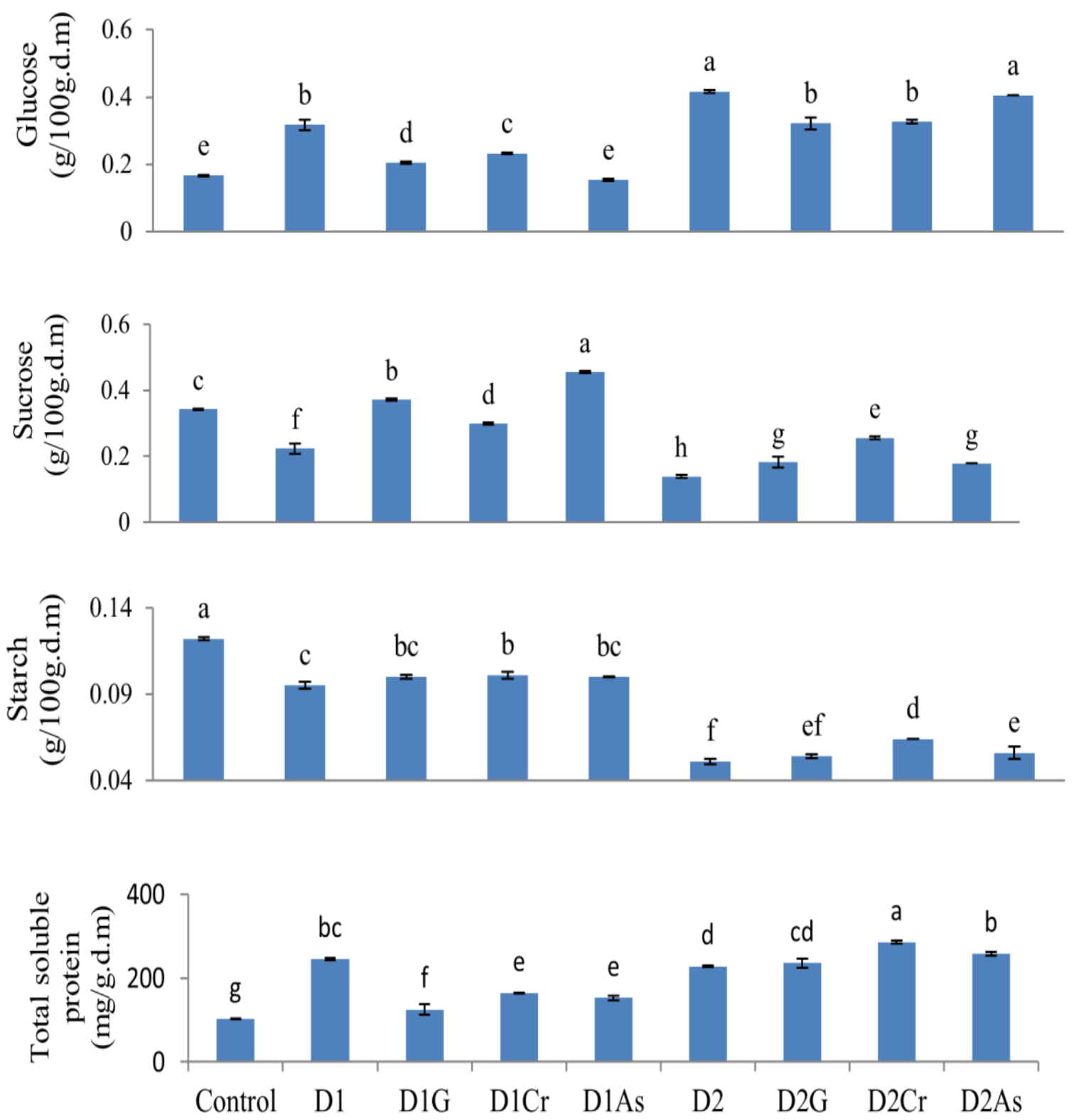

Fig. 5. Effect of drought stress on glucose, sucrose, starch and total soluble proteins in the leaves of 40 daysold Vicia faba plants after presoaking the seeds for $10 \mathrm{~h}$ in either of $100 \%$ garlic (G), $100 \%$ carrot $(\mathrm{Cr})$ extracts or $0.5 \mathrm{mM}$ ascorbic acid (As). D1 and D2= water withholding for 14 and 22 days, respectively. Bars indicate standard errors between three replicates. Treatments labeled with identical letters are not significant at $\mathbf{p} \leq \mathbf{0 . 0 1}$.

One way ANOVA analysis $(\mathrm{P} \leq 0.01)(* * *$ highly significant $)$

$\begin{array}{lccc}\text { Parameter } & \text { LSD } & \text { F } & \text { Significance } \\ \text { Glucose } & 0.02 & 411.5 & * * * \\ \text { Sucrose } & 0.02 & 465.5 & * * * \\ \text { Starch } & 0.004 & 681.7 & * * * \\ \text { Total soluble protein } & 14.3 & 337.5 & * * *\end{array}$




\section{Discussion}

The two levels of drought stress (D1 \& D2) resulted in a significant increase in root length of Vicia faba, while they caused a significant decline in growth parameters which were consistent with the results of Ammar et al. (2015) for Vicia faba (genotypes; Goff-1, Hassawi-1 and Gazira-2). This increase in root length may be to help plants to absorb water and minerals from the soil (Aslam et al., 2013). Meanwhile, the decline in shoot height and leaf area may be due to either the decrease in cell elongation resulting from the inhibiting effect of water shortage on growth promoting hormones which, in turn, led to a decline in each of cell turgor, cell volume and eventually cell growth (Anjum et al., 2011 and Kusvuran, 2012). Alternatively, it may be due to early senescence (Farooq et al., 2012), and/ or to blocking the xylem and phloem vessels thus hindering any translocation (Ammar et al., 2015).

Drought stress caused a reduction in Chl.a, Chl.b and the $\mathrm{Chl} . \mathrm{a} / \mathrm{b}$ ratio which were in harmony with the results of El-Tayeb (2006) for faba bean (cv. Giza 667). This reduction may be due to impaired chlorophyll biosynthesis (Ashraf \& Harris, 2013), to accelerated breakdown of chlorophyll rather than its slow synthesis (Kaewsuksaeng, 2011), to pigment peroxidation (Amin et al., 2009), or due to damage of chloroplast structure (Kasim, 2007; Kasim et al.,2014 and Mahmoud, 2014) and distortion of its lipids and proteins (Anjum et al., 2011).The decrease in $\mathrm{a} / \mathrm{b}$ ratio may reflect higher reduction in Chl. a than in $\mathrm{Chl} b$ which may be considered as a defense mechanism of the plant against drought stress by keeping its Chl.b content as stable as possible to playits dual role in protecting Chl.a and in light harvesting. Meanwhile, both D1 and D2 resulted in an increase in carotenoids which was in accordance with the results obtained by Mohamed \& Akladious (2014) in soybean (cv. Giza 22). This increase may be due to the role of carotenoids in protecting chlorophylls from photooxidative destruction (Devlin \& Withman, 2002 and Abbas \& Akladious, 2013).

Exposure of faba beans to either D1 or D2 resulted in the decrease in the photosynthetic activity $(\mathrm{fv} / \mathrm{fm})$. This result is in agreement with that of Abid et al. (2016) and Ammar et al. (2017) who found that this ratio should vary between 0.75 and 0.85 for healthy leaves and its decline reflects the damage and in efficiency of PSII.
In the present study, drought stress resulted in the increase of ascorbic acid, MDA and the activities of CAT and POD in Vicia faba leaves. This is in accordance with the results of Ammar et al. (2015) and Siddiqui et al. (2015) for faba beans. The increase of MDA may have resulted from the production of ROS under drought stress which can directly attack membrane lipids causing damage to cellular membranes especially those of the chloroplasts (Anjum et al., 2011 and Kapoor et al., 2015). However, the increase in CAT and POD activities may help in a better protection mechanism against oxidative damage under water stress (Kusvuran et al., 2016). The decline in POD activity in case of D2 may be due to the inhibition of enzyme synthesis or change in the assembly of enzyme subunits under stress conditions (Abedi \& Pakniyat, 2010). The recorded increase in the ascorbic acid content may be due to its important roles as ROS scavenger,in the synthesis of collagen (which increases the tolerance of plants to oxidative stresses (Yazdanpanah et al., 2011) and in the ascorbate-glutathione cycle in mitochondria and peroxisomes (Darvishan et al., 2013).

Plants adapt to drought stress through synthesis of osmoprotectants (osmolytes or compatible solutes) which are low-molecular-weight and highly soluble compounds that are usually nontoxic even at high cytosolic concentrations (Tekle \& Alemu, 2016). D1 and D2 caused a significant increase in glucose and total soluble protein contents of Vicia faba leaves. These results are in harmony with those of Abdalla (2011) and Mohamed \& Akladious (2014). This increase can protect the cell under stress by balancing the osmotic strength of the cytosol with that of the vacuole and the external environment (Anjum et al., 2011). On the other hand, both D1 and D2 resulted in highly significant reductions in sucrose and starch contents of Vicia faba leaves which agreed with the findings of Liu et al. (2004), and may be due to increased starch hydrolysis (Bartels \& Sunkar, 2005) or to reduced photosynthesis (Yazdanpanah et al.,2011).

The enhancement of all growth parameters and Chl.a, Ch.b and a/b ratio by priming of Vicia faba seeds with garlic $(\mathrm{G})$, carrot $(\mathrm{Cr})$ extracts or ascorbic acid (As) may be due to the presence of vitamin C (ascorbic acid), auxin substances (IAA), gibberellic acids, kinetin and benzyl adenine as cytokinins, $\mathrm{K}, \mathrm{P}, \mathrm{Mg}$ and $\mathrm{Zn}$ in garlic and carrot (Table 1), in addition to folic acid in carrot as 
reported by Burguieres et al. (2007). These ingredients are known to improve the growth and increase cell division and cell enlargement (Waraich et al., 2011; Hasanuzzaman et al.,2013 and Ahmed et al., 2014). This might explain the remarkable increase in root length, shoot height, leaf area and root water content of the primed bean plants even than their control counter parts. Furthermore, priming with the extract of garlic or carrot was more effective than with ascorbic acid which plays a regulatory role in growth by modulating the synthesis of plant hormones such as gibberellic and abscisic acids and ethylene (Pastori et al., 2003).

Water content increased in all primed and drought stressed plants and this increase may be helpful to continue physio-biochemical processes efficiently under water stress conditions and to act as a resistance mechanism to drought stress (Moussa \& Abdel-Aziz, 2008 and Keyvan, 2010). In this regard, priming with garlic and carrot was more effective than ascorbic acid and this may be due to the presence of vitamin $C$ in both garlic and carrot and vitamin $\mathrm{A}$ (as $\beta$-carotene) in carrot (Table 1) which may act as ROS scavengers resulting in improvement of growth, better protection for chlorophyll, decreased MDA, reduced CAT and POD activities and less glucose content. Interestingly, $\mathrm{Mg}$ and $\mathrm{Ca}$ were detected in both garlic and carrot (Table 1) and it is well known that $\mathrm{Mg}$ is essential for chlorophyll synthesis (Waraich et al., 2011) while Cacan prevent cell membrane injury under stressful environmental conditions (Mohamed \& Akladious, 2014). $\mathrm{Cu}$ was found in garlic and carrot extracts; it plays an essential role in carbohydrate metabolism (Waraich et al., 2011), whereas $\mathrm{P}$ and $\mathrm{K}$ are important requirements in the biosynthesis and translocation of carbohydrates (Saeidi-Sar et al. 2013 and Abdul Qados, 2014). Therefore, priming of Vicia faba seeds with G, Cr or As elevated the content of endogenous ascorbate with D1 but reduced it in case of (D2) which indicates that the primed plants may change their defense mechanism against prolonged drought by increasing their total soluble protein content instead of increasing ascorbic acid production.

In the light of the present study, it seems reasonable to suggest that priming the seeds of Vicia faba with the extracts of garlic cloves or carrot roots or with as corbic acid can successfully ameliorate the deleterious effects of the two levels of drought stress as well as enhance the plants' growth. Furthermore, it is worth noting that the two extracts were more effective than ascorbic acid in raising the plants' tolerance to drought. Therefore, we would venture to recommend the use of priming Vicia faba seeds with either garlic or carrot extract as a new natural and low-cost method for not only the alleviation of drought stress on the plants but also for stimulating their growth with no discernible adverse effects.

\section{References}

Abass, S.M. and Mohamed, H.I. (2011) Alleviation of adverse effects of drought stress on common bean (Phaseolus vulgaris L.) by exogenous application of hydrogen peroxide. Bangladesh Journal of Botany, 41, 75-83.

Abbas, S.M. and Akladious, S.A. (2013) Application of carrot root extract induced salinity tolerance in cowpea (Vigna sinensis L.) seedlings. Pakistan Journal of Botany, 45, 795-806.

Abdalla, M.M. (2011) Beneficial effects of diatomite on the growth, the biochemical contents and polymorphic DNA in Lupinus albus plants grown under water stress. Agriculture and Biology Journal of North America, 2, 207-220.

Abdelmula, A.A., Gasim, S.M., Link, W., Mohamed, A.A. and Khalifa, J.E, (2012) Genotypic variability in faba bean (Vicia faba L.) for seed yield and protein content under drought stress during vegetative and reproductive stages. University of Khartoum Journal of Agricultural Sciences, 20 (1), $1-25$.

Abdul Qados, A.M.S. (2014) Effect of ascorbic acid antioxidant on soybean (Glycine max L.) plants grown under water stress conditions. International Journal of Advanced Research in Biological Sciences, 1 (6), 189-205.

Abedi, T. and Pakniyat, H. (2010) Antioxidant enzyme changes in response to drought stress in ten cultivars of Oil seed Rape (Brassica napus L.). Czech Journal of Genetics and Plant Breeding ,46, 27-34.

Abid, G., Aouida, M., Aroua, I., Souissi, F., Mannai, K., Jebara, M., M'hamdi, M., Mingeot, D., Muhovski, Y. and Sassi, K. (2016) Effect of drought stress on chlorophyll fluorescence, antioxidant enzyme 
activities and gene expression patterns in faba bean (Vicia faba L.). Archives of Agronomy and Soil Science, 63 (4), 536-552.

Ahmed, F., Baloch, D.M., Sadiq, S.A., Ahmed, S.S., Hanan, A., Taran, S.A., Ahmed, N. and Hassan, M.J. (2014) Plant growth regulators induced drought tolerance in sunflower (Helianthus annuus L.) hybrids. The Journal of Animal and Plant Sciences, 24 (3), 886- 890.

Allen, S.G., Girmshaw, H.M., Parkinson, J.A. and Quarmby, C. (1974) "Chemical Analysis of Ecological Materials". Black Well Science Publishers, Oxford and London.

Amin, B., Mahleghah, G., Mahmood, H.M.R. and Hossein, M. (2009) Evaluation of interaction effect of drought stress with ascorbate and salicylic acid on some of physiological and biochemical parameters in okra (Hibiscus esculentus L.). Research Journal of Biological Sciences, 4(4), 380-387.

Ammar, M.H., Anwar, F., El-Harty, E.H., Migdadi, H.M., Abdel-khalik, S.M., Alghamdi, S.S., AlFaifi, S.A. and Farooq, M. (2015) Physiological and yield responses of faba bean (Viciafaba L.) to drought stress. Journal of Agronomy and Crop Science, 201(4), 280-287.

Ammar, M.H., Khan, A.M., Migdadi, H.M., Abdelkhalek, S.A, and Alghamdi, S.S. (2017) Faba bean drought responsive gene identification and validation. Saudi Journal of Biological Sciences, 24 (1), 80-89.

Anjum, S.A., Xie, X., Wang, L., Saleem, M.F., Man, C. and Lei, W. (2011) Morphological, physiological and biochemical responses of plants to drought stress. African Journal of Agricultural Research, 6 (9), 2026-2032.

AOAC (1990) "Official Methods of Analysis" of the Association of Official Analytical Chemists,. $15^{\text {th }}$ ed., Washington, D.C.

Ashraf, M. and Harris, P.J.C. (2013) Photosynthesis under stressful environments: an overview. Photosynthetica, 51 (2), 163-190.

Aslam, M., Zamir, M.S.I., Afzal, I., Yaseen, M., Mubeen, M. and Shoaib, A. (2013) Drought stress, its effect on maize production and development of drought tolerance through potssiumm application.
Cercetări Agronomiceîn Moldova, 2 (154), 99-114.

Athar, H., Khan, A. and Ashraf, M. (2008) Exogenously applied ascorbic acid alleviates salt-induced oxidative stress in wheat. Environmental and Experimental Botany, 63 (2), 224-231.

Baranska, M., Schulz, H., Baranski, R., Nothnagel, T. and Christensen, L.P. (2005) In situ simultaneous analysis of polyacetylenes, carotenoids and polysaccharides in carrot roots. Journal of Agricultural and Food Chemistry, 53 (17), 65656571.

Bartels, D. and Sunkar, R. (2005) Drought and salt tolerance in plants. Critical Reviews in Plant Sciences, 166, 117-123.

Bradford, M.M. (1976) A rapid and sensitive method for the quantification of microgram quantities of protein utilizing the principle of protein dye binding. Analytical Biochemistry 72 (1-2), 248-254.

Burguieres, E., McCue, P., Kwon, Y. and Shetty, K. (2007) Effect of vitamin $C$ and folic acid on seed vigour response and phenolic-linked antioxidant activity. Bioresource Technology, 98, 1393-1404.

Darvishan, M., Tohidi-Moghadam, H.R. and Zahedi, H. (2013) The effects of foliar application of ascorbic acid (vitamin $\mathrm{C}$ ) on physiological and biochemical changes of corn (Zea mays L) under irrigation withholding in different growth stages. Maydica, 58 (2), 195-200

Devlin, M.R. and Withman, H. (2002) "Plant Physiology".GBS Publishers Distributors Delhi, India, pp.12.

Dubois, M., Gilles, K.A., Hamilton, J.K., Rebers, P.A. and Smith, F. (1956) Colorimetric method for determination of sugars and related substances. Analytical Chemistry, 28 (3), 350 - 356.

El-Beltagi, H.S. and Mohamed, H.I. (2013) Alleviation of cadmium toxicity in Pisum sativum L. seedlings by calcium chloride. Notulae Botanicae Horti Agrobotanici Cluj-Napoca, 41 (1), 157- 168.

El-Tayeb, M.A. (2006) Differential responses of pigments, lipid per-oxidation organic solutes, catalase and per-oxidase activity in the leaves of two Vicia faba L. cultivars to drought. International Journal of Agriculture and Biology, 8 (1), 16 -122. 
Environmental Protection Agency (EPA) (1991)"Methods of Determination of Metals in Environmental Samples".Office of Research and Development Washington DC., pp. 23-29 and 83122.

Farooq, M., Hussain, M., Wahid, A. and Siddique, K.H.M. (2012) Drought stress in plants: An Overview. In: "Plant Responses to Drought Stress "(Ed. R. Aroca), pp.1-33. Springer Press, Berlin Heidelberg.

Hanafy, M.S., Saadawy, F.M., Milad, S.M.N. and Ali, R.M. (2012) Effect of some natural extracts on growth and chemical constituents of Schefflera arboricola plants. Journal of Horticultural Scienceand Ornamental Plants, 4 (1), 26-33.

Hasanuzzaman, M., Nahar, K. and Fujita, M. (2013) Plant response to salt stress and role of exogenous protectants to mitigate salt-induced damages. In:"Ecophysiology and Responses of Plants under Salt Stress". Springer Science+Business Media, (Ahmad, P. et al., Ed.), pp. 25-87.

Heath, R.L. and Packer, L. (1968) Photoperoxidation in isolated chloroplasts. I. Kinetics and stoichiometry of fatty acid peroxidation. Archives of Biochemistry and Biophysics, 125 (1), 189-198.

Kaewsuksaeng, S. (2011) Chlorophyll degradation in horticultural crops. Walailak Journal of Science and Technology, 8 (1), 9-19.

Kapoor, D., Sharma, R., Handa, N., Kaur, H., Rattan, A., Yadav, P., Gautam, V., Kaur, R. and Bhardwaj, R. (2015) Redoxhomeostasis in plants under abiotic stress: role of electron carriers, energy metabolism mediators and proteinaceous thiols. Frontiers in Enviromental Science, 3 (13). DOI: 10.3389/ fenvs.2015.00013.

Kasim, W.A. (2007) Physiological consequences of structural and ultra-structural changes induced by zinc stress in Phaseolus vulgaris. 1. Growth and photosynthetic apparatus. International Journal of Botany, 3 (1), 15-22.

Kasim,W.A..,Abokassem, E.M., Ragab, G.A. and Sewelam, N.A. (2014) Alleviation of lead stress toxicity in Vigna unguiculata by salicylic acid. Egyptian Journal of Experimental Biology, (Botany), 10 (1), $37-49$.
Kato, M. and Shimizu, S. (1987) Chlorophyll metabolism in higher plants.VII-chlorophyll degradation in senescing tobacco leaves; phenolicdependent peroxidative degradation. Canadian Journal of Botany, 65 (4), 729-735.

Khazaei, H. (2014) Leaf traits associated with drought adaptation in faba bean (Vicia faba L.). Ph.D. thesis, Faculty of Agriculture and Forestry, University of Helsinki, Finland.59 pp.

Keyvan, S. (2010) The effects of drought stress on yield, relative water content, proline, soluble carbohydrates and chlorophyll of bread wheat cultivars. Journal of Animal and Plant Sciences, 8 (3), 1051- 1060.

Kusvuran, S. (2012) Influence of drought stress on growth, ion accumulation and antioxidative enzymes in okra genotypes sebnemkusvurani. International Journal of Agriculture and Biology, 14 (3), 401-406.

Kusvuran, S., Kiran, S. and Ellialtioglu, S.S. (2016) Antioxidant enzyme activities and abiotic stress tolerance relationship in vegetable crops.Chapter 21 in: "Abiotic and Biotic Stress in PlantsRecent Advances and Future Perspectives", Dr. ArunShanker (Ed.), pp. 481-506 .In Tech.

Liu, F., Jensen, C.R. and Andersen, M.N. (2004) Drought stress effect on carbohydrate concentration in soybean leaves and pods during early reproductive development: its implication in altering pod set. Field Crops Research, 86 (1), 1-13.

Mahmoud, A.A.S. (2014) Suppresion of weeds growing with Vicia faba by glucosinulates of some species of Brassicaceae as compared with the herbicide fusilade. Ph.D. Thesis, Faculty of Science, Tanta University, Egypt. 247 pp.

Metzner, H., Rau, H. and Senger, H. (1965) Untersuchungen Zur synchronisierberkeit einzelner pigmentmangen Mutanten von chlorella. Planta, 65, 186-194.

Mohamed, H.I. and Akladious, S.A. (2014) Influence of garlic extract on enzymatic and non enzymatic antioxidants in soybean plants (Glycine Max) grown under drought stress. Life Science Journal, 11 (3s), 46-58.

Moussa, H.R. and Abdel-Aziz, S.M. (2008) Comparative response of drought tolerant and drought sensitive 
maize genotypes to water stress. Australian Journal of Crop Sciense, 1 (1), 31-36.

Naguib, M.I. (1963) Colorimetric estimation of plant polysaccharides. Zucher, 16, 15.

Nelson, N. (1944) A photometric adaptation of Somogi method for the determination of glucose. Biol. Chem. 153, 275.

Oser, B. (1979) "Hawk's Physiological Chemistry", 15 ${ }^{\text {th }}$ ed., McGrow Hill Publish. Company, New York.

Pastori, G., Kiddle, G., Antoniw, J., Bernard, S., Veljovic-Jovanovic, S., Verrier, P.J., Noctor, G. and Foyer, C.H. (2003) Leaf vitamin C contents modulate plant defense transcripts and regulate genes that control development through hormone signaling. Plant Cell, 15, 939-951.

Saeidi-Sar, S., Abbaspour, H., Afshari, H. and Yaghoobi, S.R. (2013) Effects of ascorbic acid and gibberellin A3 on alleviation of salt stress in common bean (Phaseolus vulgaris L.) seedlings. Acta Physiologia Plantarum, 35, 667-677.

Samarah, N.H. (2005) Effect of drought stress on growth and yield of barley. Agronomy for Sustainable Development, 25, 145-149.

Shindy, W.W. and Smith, O.E. (1975) Identification of Plant Hormones from Cotton Ovules. Plant Physiology, 55 (3), 550-554.

Siddiqui, M.H., Al-Khaishany, M.Y., Al-Qutami, M.A., Al-Whaibi, M.H., Grover, A., Ali, H.M., AlWahibi, M.S. and Bukhari, N.A. (2015) Response of different genotypes of faba bean plant to drought stress. International Journal of Molecular Sciences, 16 (5),10214-10227.

Sofowora, A. (1982) "Medicinal plants and traditional medicine in Africa". John Wiley Chichester, pp. 179.

Tekle, A.T. and Alemu, M.A. (2016) Drought tolerance mechanisms in field crops. World Journal of Biology and Medical Sciences, 3 (2), 15-39.

Waraich, E.A., Ahmad, R. Saifullah and Ashraf, M.Y. Ehsanullah (2011) Role of mineral nutrition in alleviation of drought stress in plants. Australian Journal of Crop Science, 5 (6), 764-777.

Yazdanpanah, S., Baghizadeh, A. and Abbassi, F. (2011) The interaction between drought stress and salicylic and ascorbic acids on some biochemical characteristics of Satureja hortensis. African Journal of Agricultural Research, 6 (4), 798-807.

Yu, C-M., Xie, F-D. and Ma, L-J. (2014) Effects of exogenous application of ascorbic acid on genotoxicity of $\mathrm{Pb}$ in Vicia faba roots. International Journal of Agriculture and Biology, 16(4), 831-835. 
تخفيف إجهاد الجفاف فى نبات الفول بنقع البذرة فى حض الأسكوربيك أو فى مستخلص الثوم والجزر

وداد عبد العزيز قاسم، عفاف عاطف نسيم و عزة جابر

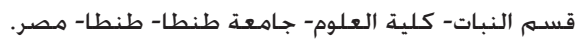

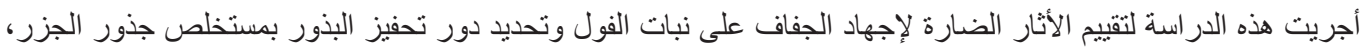

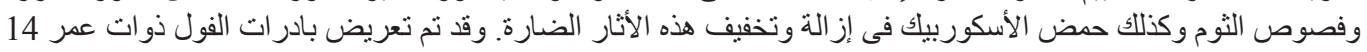

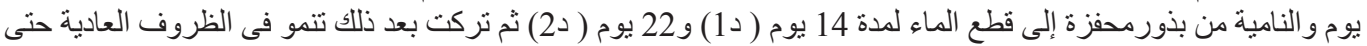

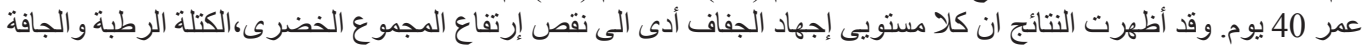

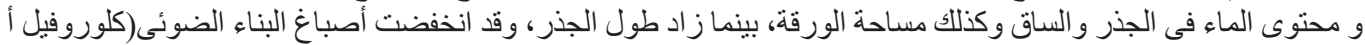

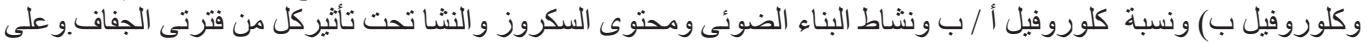

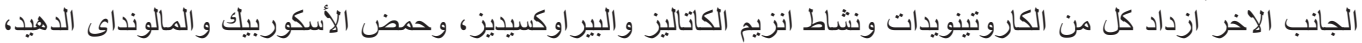

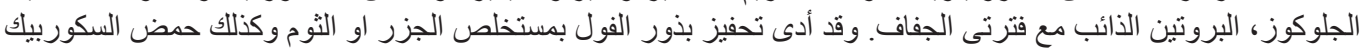

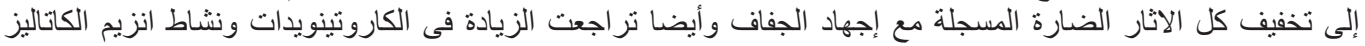

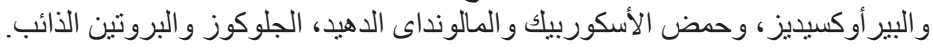

